\title{
EFFECT OF THE MOISTURE INCREASE IN THE TESTINGS OF DENSITY AND SATURATION DEGREE FOR MINE SOIL AT A CONSTANT SPECIFIC GRAVITY CONDITION
}

\author{
PENGARUH PENINGKATAN KADAR AIR DALAM PENGUJIAN \\ BOBOT ISI DAN DERAJAT JENUH TANAH TAMBANG \\ PADA KONDISI BERAT JENIS TETAP
}

\author{
DEDEN A. AHMID, BAGARAJA SIRAIT, YAYAH ROHAYATI and TARSONO \\ R\&D Centre for Mineral and Coal Technology \\ Jalan Jenderal Sudirman 623 Bandung 40211 \\ Phone (+6222) 6030483, Fax. (+6222) 6003373 \\ e-mail: deden.agus@esdm.go.id
}

\begin{abstract}
The degree of density and saturation in soil sample under constant specific gravity conditions are influenced by the addition of water content. To find out its effect, it is necessary to test the samples which include compaction, moisture content, specific gravity and density testing. By recognizing the soi properties through a testing and calculation; dry density, saturation density, dry soil volume, pore volume, degree of saturation, porosity, and void ratio can be evaluated. The test shows that the optimum moisture content and dry density are $53,25 \%$ and $1.08 \mathrm{~g} / \mathrm{cm} 3$ respectively. The tests were conducted to five samples that have a specific gravity of 2.67 . The obtained saturation degree were S-01: $79.05 \%, \mathrm{~S}-02$ : 92.40\%, S-03: $95.06 \%$, S-04: $94.64 \%$ and S-05: $93.12 \%$. The value of water content in the five samples was S-01: 48.87\%, S-02: $51.04 \%$, S-03: $53.25 \%$, S-04: $55.32 \%$, S-05: $57.24 \%$. The densities in five samples were S-01: $1.50 \mathrm{~g} / \mathrm{cm}^{3}$, S-02: $1.63 \mathrm{~g} / \mathrm{cm}^{3}$, S-03: $1.64 \mathrm{~g} / \mathrm{cm}^{3}, \mathrm{~S}-04: 1.62 \mathrm{~g} / \mathrm{cm}^{3}, \mathrm{~S}-05: 1.59 \mathrm{~g} / \mathrm{cm}^{3}$ The saturation degree will increase along with the addition of the water content and the density. However, beyond the optimum addition of the moisture content, the saturation degree will decrease in line with the density even though if the water content increase. This occurred in the constant condition of the specific gravity.
\end{abstract}

Keywords: moisture content, optimum moisture content, specific gravity, density, degree of saturation.

\begin{abstract}
ABSTRAK
Pada kondisi berat jenis tetap, densitas dan derajat jenuh percontoh tanah dipengaruhi oleh penambahan kadar air. Untuk mengetahui pengaruh tersebut, perlu dilakukan pengujian percontoh tanah yang terdiri atas pengujian kompaksi, kadar air, berat jenis dan bobot isi. Dengan mengetahui nilai kadar air; berdasarkan perhitungan, berat jenis dan bobot isi tanah tersebut akan diperoleh bobot isi kering, densitas jenuh, porositas, dan angka pori. Dari kegiatan pengujian sifat fisik yang dilakukan terhadap percontoh tanah untuk mengetahui pengaruh peningkatan kadar air, didapat kadar air optimum $53,25 \%$ dan densitas kering 1,08 g/cm $\mathrm{cm}^{3}$. Nilai derajat jenuh berturut turut S-01: 79,05 \%, S-02: 92,40\%, S-03:95,06 \%, S-04: 94,64 \% dan S-05: 93,12 \%. Kadar air S-01: 48,87 \%, S-02: 51,04 \%, S-03: 53,25 \%, S-04: 55,32 \%, S-05: 57,24 \%.Nilai densitas S-01: $1,50 \mathrm{~g} / \mathrm{cm}^{3}, \mathrm{~S}-02 ; 1,63 \mathrm{~g} / \mathrm{cm}^{3}, \mathrm{~S}-03: 1,64 \mathrm{~g} / \mathrm{cm}^{3}, \mathrm{~S}$ 04: $1,62 \mathrm{~g} / \mathrm{cm}^{3}, \mathrm{~S}-05: 1,59 \mathrm{~g} / \mathrm{cm}^{3}$. Derajat jenuh akan meningkat seiring dengan penambahan kadar air dan bobot isi. Akan tetapi setelah melewati kondisi penambahan kadar air optimum, derajat jenuh tersebut akan menurun sejalan dengan penurunan bobot isi meskipun kadar airnya bertambah karena berat tanah keringnya menurun. Hal ini terjadi pada kondisi berat jenis yang tetap.
\end{abstract}

Kata kunci: kadar air, kadar air optimum, berat jenis, bobot isi asli, derajat jenuh. 


\section{INTRODUCTION}

To determine the effect of water addition on the density and the saturation degree of soil sample, compaction testing is necessary. Besides that, it is also necessary to test the physical properties of the soil samples.

The physical properties of soils influence the use of either agricultural or non agricultural purposes. Physical characteristics of mine soil must be controlled for its utilization in reclamation or post mine activities. During mining activities, the soils have important physical properties for determining the infiltration rate, drainage practices and other hydrological processes. Soil moisture is a primary important variable to the environment. It is significantly affected by the weather and climate, plant growth and productivity, hydrology, and soil ecology. So, the need for information on soil moisture and other soil characteristics is purposeful (Pan et al., 2012).

There are various physical properties in the soils such as water content, specific gravity, and natural density. Some researchers focus on the efforts in developing the new techniques for monitoring soil moisture and their effects to other parameters. After understanding the physical properties of the soil through a series of testings then the dry density, saturation density, dry soil volume, pore volume, degree of saturation, porosity, and void ratio can be calculated. Determining the soil's saturation degree is based on testing the physical properties of the soil. Based on the explanation, examining the soil's physical properties such as water content, gravity, and density, is determined after adding the water to the five samples until they reach an optimal condition.

The purpose of this test is to obtain the optimal moisture content parameters and maximum dry density (ASTM D698 and ASTM D 1557). The condition of the soil with an optimal water content described as the soils that bear the capacity of the optimal load as well.

The requirement for civil engineering construction is that the material should be in the optimal condition. The soil which is the foundation of a structure should reach the optimal condition to support the existing structure on it (Sembiring, Iswan and Jafri, 2016).
This paper informs the results of compaction testing on soil samples (optimal water content and density). Compaction testing in determining the bearing capacity of the soil which the load above is commonly accomplished.

There are other research related to these issues, both in civil engineering and mining project. Muda (2016) investigated the modelling approach for tools of compaction testing in laboratory for clay soil. Novalia (2017) studied the comparison degree of compaction between the Standard Proctor and the Modified Proctor on selected soil samples. Ulfa (2017) studied the energy conversion in soil compaction using a modified proctor method for clayey sand soil. Yamali (2016) analyzed the energy of soil compaction that is needed in the field for clay soil. In mining projects, Tuheteru, Gautama and Kusuma (2016) studied the characteristics of some types of overburden rock after compaction used for capping materials the on encapsulation method. Syafruddin (2007) studied the theoretical relationship between the dry density and the water content to determine its relative density.

Another objective of this study is to evaluate the physical properties of the soil such as dry density, saturated density, dry soil volume, pore volume, saturation degree, porosity, and void ratio and the influence of water addition to those parameters (Al-Khafaji and Andersland, 1992). It is also to seek the optimum water content and dry density of the sampel as noted in ASTM D698-00 (2012). These parameters become the characteristics of topsoil sample and a consideration for engineers for its usage in civil or mining projects.

\section{METHOD}

To carry out the compaction test, 5 plastic bags of soil with a weight of 2,500 g were needed. The required soil samples should pass through 4.75-mesh sieve. Water from 1 to $3 \%$ of the soil sample weight was added to 5 soil plastic bags and each contained 2,500 $\mathrm{g}$ in varying amounts. The compaction test was carried out using the standard of American Society for Testing and Materials, ASTM D 698-00.

The soil moisture is defined as the ratio of the weight of water in the pores of a soil to the 
weight of soil solids (Bowles, 1984). The purpose of testing the water content was to obtain the moisture content of the test specimen.

Water content was obtained by the formula as follows:

$$
\begin{aligned}
& W_{i}=\frac{W_{2}-W_{3}}{W_{3}-W_{1}} \\
& \mathrm{~W}_{\mathrm{i}} \quad=\text { initial water content, } \% \\
& \mathrm{~W}_{1} \quad=\text { tare weight, gram } \\
& \mathrm{W}_{2} \quad=\text { tare weight }+ \text { wet soil, gram } \\
& \mathrm{W}_{3}=\text { tare weight }+ \text { dry soil, gram } \\
& W_{2}-W_{3}=\text { water weight, gram } \\
& W_{3}-W_{1}=\text { dry soil weight, gram }
\end{aligned}
$$

Specific gravity is the ratio between the soil's weight and distilled water in the air with the same content and certain temperature (Das and Sobhan, 2016). Soil specific gravity calculation was formulated as follows:

$G_{s}=\frac{W_{2}-W_{1}}{\left(W_{4}-W_{1}\right)-\left(W_{3}-W_{2}\right)}$

Where:

$\mathrm{G}_{\mathrm{s}}=$ specific gravity

$\mathrm{W}_{1}=$ picnometer weight, gram

$\mathrm{W}_{2}=$ picnometer weight + dry soil, gram

$\mathrm{W}_{3}=$ picnometer weight + dry soil + water, gram

$\mathrm{W}_{1}=$ picnometer weight + water, gram

Unit weight of soil (dry, wet, and submerged) or density was given as weight per unit volume material (Bowles, 1991). The compaction testing was the main tools to know the influence of adding water on the density and the degree of saturation of soil samples. The wet density $(\gamma)$ was formulated as follows:

$\gamma=\frac{B_{2}-B_{1}}{V}$

$\gamma=$ wet density, $\mathrm{g} / \mathrm{cm}^{3}$

$\mathrm{B}_{1}=$ mold weight, $\mathrm{g}$

$B_{2}=$ mold weight + speciment, $g$

$\mathrm{V}=$ volume, $\mathrm{m}^{3}$

and the dry density was formulated as follows:

$\gamma_{\mathrm{d}}=\frac{\gamma \times 100}{(100+\mathrm{w})}$

$\gamma=$ dry density, $\mathrm{g} / \mathrm{cm}^{3}$

$\mathrm{W}=$ water content, $\%$

Saturation degree $(\mathrm{S})$ is the ratio between the water weight and the pore volume in percent unit percentage and is formulated as follows:
$\mathrm{S}=\left(\mathrm{W}_{\mathrm{a}} / \mathrm{V}_{\mathrm{p}}\right) \times 100 \%$

$\mathrm{Wa}=$ water weight

$\mathrm{Vp}=$ pore volume

$\mathrm{W}_{\mathrm{a}}=\mathrm{W}_{2}-\mathrm{W}_{3}$

$\mathrm{W}_{1}=$ tare weight, gram

$\mathrm{W}_{2}$ = tare weight + wet weight, gram

$\mathrm{W}_{3}=$ tare weight + dry weight, gram

$\mathrm{V}_{\mathrm{p}}=$ mold volume - dry soil volume

$\mathrm{V}_{\mathrm{d}}=\left(\mathrm{W}_{\mathrm{d}} / \mathrm{S}_{\mathrm{G}}\right)$

From equations (5), (6) and (7) was obtained the equation as follows:

$\mathrm{S}=\left(\left(\mathrm{W}_{2}-\mathrm{W}_{3}\right) /\left(\mathrm{V}_{\mathrm{c}}-\mathrm{W}_{\mathrm{d}} / \mathrm{S}_{\mathrm{G}}\right)\right) \times 100 \%$

$\mathrm{V}_{\mathrm{c}}=$ mold volume

\section{RESULTS AND DISCUSSION}

\section{Soil Compaction}

Compaction is the densification of soil by applying mechanical energy to produce particle packing. Compaction energy in the field can be obtained from rollers, vibratory devices, and falling weights. In the laboratory, test samples for establishing quality control are compacted using impact (or dynamics), kneading devices or static pressure using piston and compression machine (Bowles, 1991). The purpose of testing the soil sample compaction was to obtain optimum water content parameters and dry density (ASTM D 689-00). In Table 1, compaction test data are shown for 5 sample plastic bags weighing $2,500 \mathrm{~g}$ each with the addition of water 100 , $150,200,250$ and $300 \mathrm{cc}$.

Table 1 shows all soil samples, adding water with a difference of $50 \mathrm{cc}$ to each soil sample. Furthermore, each soil sample was compacted, then after compaction testing, the weight of the samples was measured. Each of samples showed weight of 3,096.4, 3,216.0, $3,229.0,3,202.6$, and 3,175.2 g respectively. The optimal water condition was reached when a further addition of $50 \mathrm{cc}$ of water caused the sample's weight at a maximum before further showing a continuous decrease.

\section{Physical Properties}

The physical properties in soil material have been tested to all samples in the 
geomechanical laboratory. The physical properties which had been tested were water content, specific gravity, and density.

This paragraph shows the test data on water content that has been carried out in the initial conditions. The testing of moisture content in the initial conditions was carried out on the undisturbed specimens from the field. The five samples tested were the same sample and distinguish between one sample to another was adding the water between 1 to 3 percent weight of the sample soil. The effect of adding water will increase the sample weight and then decreased above $200 \mathrm{cc}$ of water. The sample reaches optimal water content conditions with the addition of $200 \mathrm{cc}$ of water.

\section{Water Content Test}

Table 2 shows the testing data of water content for 5 soil samples. The sample weight of each sample is $2,500 \mathrm{~g}$ and is added water of $100,150,200,250$ and 300 cc each, after compaction testing.

A small amount of soil taken from five samples was tested and put in a place called Tara for calculating the water content. Then, the soil samples were weighed before drying them in the oven. Finally, the samples weight were measured again after drying for 24 hours at $105^{\circ} \mathrm{C}$ (ASTM D2216-98, 2010). The results is presented in Table 2 . The test results of the water content can be seen in Table 6.

\section{Soil Specific Gravity Test}

The data of specific gravity for soil specimens. Specific gravity test was carried out on the original specimens from the field and was carried out only once, because the sample and its value are the same. Table 3 shows the data for two times tests of specific gravity, and then the results were averaged.

Table 1. Data of compaction test

\begin{tabular}{lcccccc}
\hline \multicolumn{1}{c}{ Sample Code } & & S-01 & S-02 & S-03 & S-04 & S-05 \\
\hline Sample Numbers & & 1 & 2 & 3 & 4 & 5 \\
Initial wet weight & $(\mathrm{g})$ & 2,500 & 2,500 & 2,500 & 2,500 & 2,500 \\
Water added & $(\mathrm{cc})$ & 100 & 150 & 200 & 250 & 300 \\
Wet weight + mold & $(\mathrm{g})$ & $3,096.4$ & $3,216.0$ & $3,229.0$ & $3,202.6$ & $3,175.2$ \\
Mold weight & $(\mathrm{g})$ & $1,673.5$ & $1,673.5$ & $1,673.5$ & $1,673.5$ & $1,673.5$ \\
Volume & $\left(\mathrm{cm}^{3}\right)$ & 946.45 & 946.45 & 946.45 & 946.45 & 946.45 \\
\hline
\end{tabular}

Table 2. Data for calculating water content

\begin{tabular}{lccccc}
\hline \multicolumn{1}{c}{ Sample Code } & S-01 & S-02 & S-03 & S-04 & S-05 \\
\hline Depth $(\mathrm{m})$ & - & - & - & - & - \\
Sample Number & 1 & 2 & 3 & 4 & 5 \\
Tarra number & $\mathrm{T} 2$ & $\mathrm{~T} 147$ & $\mathrm{~T} 35$ & $\mathrm{~T} 56$ & T8 \\
Tarra Weight + Wet Sample $\left(M_{\text {cws }}\right), \mathrm{g}$. & 102.84 & 110.61 & 105.62 & 108.23 & 119.34 \\
Tarra Weight + Dry Sample $\left(M_{c d s}\right), \mathrm{g}$. & 81.58 & 85.95 & 82.14 & 83.15 & 89.73 \\
Tarra weight $\left(M_{c}\right), \mathrm{g}$. & 38.07 & 37.64 & 38.05 & 37.81 & 38.00 \\
\hline
\end{tabular}

Table 3. Specific gravity data of the sample

\begin{tabular}{lcc}
\hline \multicolumn{1}{c}{ Sample Code } & \multicolumn{2}{c}{ Sample } \\
\hline Depth $(\mathrm{m})$ & - & - \\
Pycnometer number & 10 & 3 \\
Pycnometer weight + Samples, g & 61.015 & 61.373 \\
Pycnometer weight, g & 48.015 & 48.375 \\
Sample Weight, g & 13.000 & 12.998 \\
Temperature, ${ }^{\circ} \mathrm{C}$ & 20 & 20 \\
\hline
\end{tabular}


Just like testing the moisture content, the standard of soil sample in specific gravity testing should be fulfilled before placed and weighed in a pycnometer.

\section{Soil Density Test}

Cylindrical dimension in compacting test equipment was measured through its diameter and height while the sample weight was defined as the weight in soil's sample after compaction testing. Both data are shown in Table 4.

\section{Results of Compaction Test}

Table 5 shows the results of compaction test for 5 soil samples, namely wet weight, wet density and dry density.

Wet weight is the weight of the soil sample after compaction testing after adding water for each $50 \mathrm{cc}$ soil sample (ASTM D698-00, 2012). Wet weight of 3 (three) soil samples after the addition of water has increased. Then the next 2 (two) soil samples were added with water, the wet weight decreased.

The wet density is the weight of the soil sample divided by the volume. Similar to the wet weight, for the wet density of the soil sample, 3 (three) soil samples was increased with the addition of water, and in 2 (two) soil samples the value of wet density decreased with the addition of water. The increasing value of 3 (three) soil sample were reached before the optimum point and the other 2 (two) point were reached after that point. The compactive effort was the cause in decreasing the pore volume when water was added into the sample and then filled the pore. Using equation (4), dry density can be calculated.

\section{TEST RESULTS FOR MOISTURE CONTENT}

The purpose of conducting moisture content test was to get the moisture in initial conditions. Using Table 2 data and ASTM Standard D 2216-98, the water weight and weigh dry weight can be calculated. Based on the water content calculation formula in equation (1) and American Society for Testing and Materials (ASTM) D 2216-98, the initial moisture content was obtained as follows (Table 6). From Table 6, it can be seen that for the five samples, the value of water content increased with the addition of water.

Table 4. Soil density data

\begin{tabular}{lccccc}
\hline \multicolumn{1}{c}{ Sample Code } & S-01 & S-02 & S-03 & S-04 & S-01 \\
\hline Depth (m) & - & - & - & - & - \\
Sample Number & 1 & 2 & 3 & 4 & 5 \\
Diameter, Do (cm) & 10.16 & 10.16 & 10.16 & 10.16 & 10.16 \\
Height, Ho (cm) & 11.68 & 11.68 & 11.68 & 11.68 & 11.68 \\
Weight, W (g) & $1,422.93$ & $1,542.48$ & $1,555.49$ & $1,529.09$ & $1,501.71$ \\
\hline
\end{tabular}

Tabel 5. Results of soil compaction test

\begin{tabular}{lcccccc}
\hline \multicolumn{2}{c}{ Sample Numbers } & 1 & 2 & 3 & 4 & 5 \\
\hline Wet weight & $(\mathrm{g})$ & $1,422.93$ & $1,542.48$ & $1,555.49$ & $1,529.09$ & $1,501.71$ \\
Wet density & $\left(\mathrm{g} / \mathrm{cm}^{3}\right)$ & 1.50 & 1.63 & 1.64 & 1.62 & 1.59 \\
Dry density & $\left(\mathrm{g} / \mathrm{cm}^{3}\right)$ & 1.01 & 1.08 & 1.07 & 1.04 & 1.01 \\
\hline
\end{tabular}

Table 6. Test result for moisture content

\begin{tabular}{lccccc}
\hline \multicolumn{1}{c}{ Sample Code } & S-01 & S-02 & S-03 & S-04 & S-01 \\
\hline Depth (m) & - & - & - & - & - \\
Sample Number & 1 & 2 & 3 & 4 & 5 \\
Water Weight , $(M w)=M_{c d s}-M_{c d s}, \mathrm{~g}$. & 21.26 & 24.66 & 23.48 & 25.08 & 29.61 \\
Dry weight, ( Ms ) = M $c d s-M_{c}$, g. & 43.51 & 48.31 & 44.09 & 45.34 & 51.73 \\
Water content, (Mw/Ms ) $\times 100 \%$ & 48.87 & 51.04 & 53.25 & 55.32 & 57.24 \\
\hline
\end{tabular}




\section{Specific Gravity Test}

The purpose of specific gravity test is to obtain the value of soil specific gravity, which will be used later as parameter determine others and the nature of the soil. Using the formula for calculating specific gravity as mentioned in Equation (2) above, the specific gravity values were obtained as shown in Table 7.

Table 7. Specific gravity test results

\begin{tabular}{lc}
\hline \multicolumn{1}{c}{ Sample Code } & Sample \\
\hline Depth $(\mathrm{m})$ & - \\
Pycnometer + Sample + Water, g. & 154.62 \\
Pycnometer + Air weight at t ${ }^{\circ} \mathrm{C}$ & 146.49 \\
Specific gravity & 2.67 \\
\hline
\end{tabular}

Specific gravity testing was needed to determine one of the physical properties in the soil sample. In this case, the same soil sample was tested for compacting purpose, so the specific gravity value was only available in one sample. Therefore, from the data in Table 3, the initial weighing of the sample and after testing was added to the pycnometer with water, vacuumed, and weighed according to standard ASTM D854-
02 (2010), then the specific gravity starting was obtained (Table 7).

\section{Density Test}

Unit weight of soil (dry, wet, and submerged) or density is defined as weight per unit volume material (Bowles, 1991). Using Table 2 and the test standard ASTM D4531 86(2002) (2010), the density of the five soil samples can be calculated. The density test results can be seen in Table 8. From the table it can be seen that the density value of the first, second and third samples increased with the addition of water. Then the fourth and fifth samples of the density value decreased with the addition of water. It was caused by the compactive effort that reduced the pore volume and then filled by the water.

Figure 1 shows the results of compaction and moisture content tests.

\section{Saturation Degree}

The value of saturation degree was obtained from the calculation after testing the physical properties mentioned above. Table 9 shows the result of calculation of saturation degrees.

Table 8. The density test results

\begin{tabular}{lccccc}
\hline \multicolumn{1}{c}{ Sample Code } & S-01 & S-02 & S-03 & S-04 & S-05 \\
\hline Depth $(\mathrm{m})$ & - & - & - & - & - \\
Sample Number & 1 & 2 & 3 & 4 & 5 \\
Density, $\gamma, \mathrm{gr}_{\mathrm{cm}}{ }^{3}$ & 1.50 & 1.63 & 1.64 & 1.62 & 1.59 \\
\hline
\end{tabular}

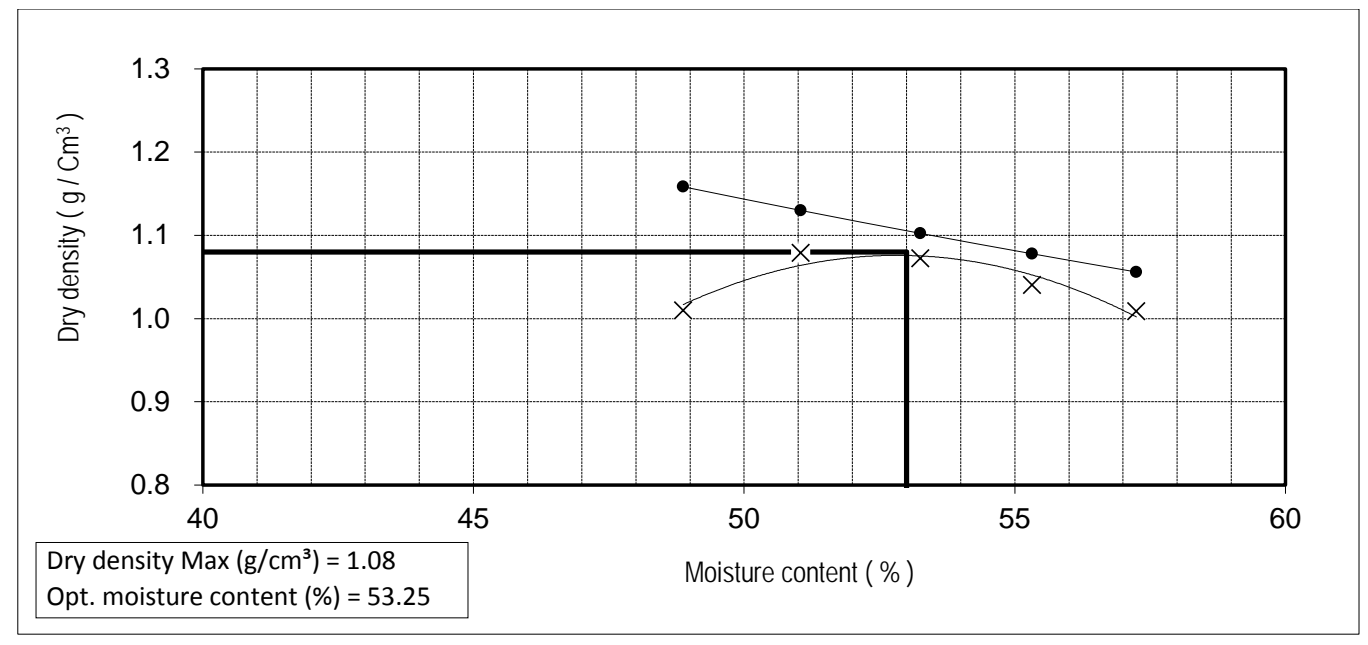

Figure 1. Dry density versus moisture content 
Table 9. The result of saturation degree calculation.

\begin{tabular}{|c|c|c|c|c|c|}
\hline a. Sample Code & S-01 & S-02 & S-03 & S-04 & S-05 \\
\hline b. Sample number & 1 & 2 & 3 & 4 & 5 \\
\hline c. Depth, m & - & - & - & - & - \\
\hline d. Mold weight, g & 0.00 & 0.00 & 0.00 & 0.00 & 0.00 \\
\hline e. Mold volume, $\mathrm{cm}^{3}$ & 946.45 & 946.45 & 946.45 & 946.45 & 946.45 \\
\hline f. Mold weight + wet soil, g & $1,419.68$ & $1,542.71$ & $1,552.18$ & $1,533.25$ & $1,504.86$ \\
\hline g. Wet soil weight $=(f)-(d), g$ & $1,419.68$ & $1,542.71$ & $1,552.18$ & $1,533.25$ & $1,504.86$ \\
\hline h. Dry soil weight, $g$ & 953.63 & 1021.39 & 1012.84 & 987.16 & 957.04 \\
\hline i. Water weight $=(\mathrm{g})-(\mathrm{h})$, gram & 466.04 & 521.32 & 539.34 & 546.09 & 547.81 \\
\hline j. Moisture content $=(\mathrm{i}) /(\mathrm{h}) \times 100, \%$ & 48.87 & 51.04 & 53.25 & 55.32 & 57.24 \\
\hline k. Specific gravity & 2.67 & 2.67 & 2.67 & 2.67 & 2.67 \\
\hline I. Natural density $=(\mathrm{g}) /(\mathrm{e}), \mathrm{gf} / \mathrm{cm}^{3}$ & 1.50 & 1.63 & 1.64 & 1.62 & 1.59 \\
\hline m. Dry density $=(\mathrm{h}) /(\mathrm{e}), \mathrm{g} / \mathrm{cm}^{3}$ & 1.01 & 1.08 & 1.07 & 1.04 & 1.01 \\
\hline n. Saturated density $=(h)+(p) /(e), g / \mathrm{cm}^{3}$ & 1.63 & 1.68 & 1.67 & 1.65 & 1.63 \\
\hline o. Dry soil volume $=(\mathrm{h}) /(\mathrm{k})$ & 356.90 & 382.26 & 379.06 & 369.44 & 358.18 \\
\hline p. Pore volume $=(e)-(0)$ & 589.55 & 564.19 & 567.39 & 577.01 & 588.28 \\
\hline q. Degree of saturation $=(i) /(p) \times 100$ & 79.05 & 92.40 & 95.06 & 94.64 & 93.12 \\
\hline r. Porosity = (p) / (e) x 100 & 62.29 & 59.61 & 59.95 & 60.97 & 62.16 \\
\hline s. Pore value $=(r) /(100-r)$ & 1.65 & 1.48 & 1.50 & 1.56 & 1.64 \\
\hline
\end{tabular}

The relationship between density, water content and degree of saturation in five soil samples that has been tested with the same density is shown in Figure 2. Graphics in Figure 2. gives information about the effect of water addition on density and the degree of saturation. The increasing moisture content was caused by the water addition. This increasing value will cause the inclined value of density up to 1.64 and degree of saturation up to $95.10 \%$ and further these two parameters will decline.

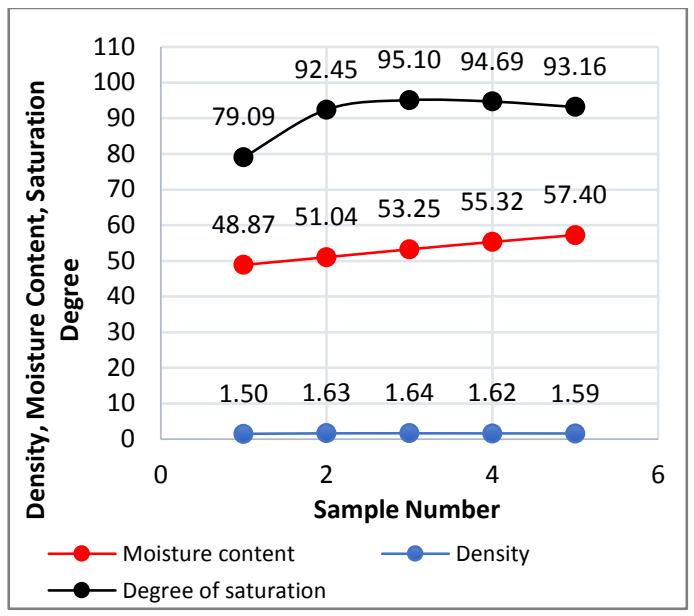

Figure 2. The relationship between density, moisture content and saturation degree in the five tested samples

\section{CONCLUSIONS}

The relationship of water content, density, and degree of saturation in the 5 tested soil samples under constant specific gravity conditions, it concluded that with the addition of water, the degree of saturation and soil density will increase until water content reaches optimum conditions. After passing these condition, the degree of saturation and density will decrease even though the water content has increased. These values will then be used as a reference for preparing field compaction using a roller compactor in terms of increasing soil bearing capacity and supporting the structure on it. It is also used as capping material in the encapsulation method and constructing an embankment in a roadway or railway.

\section{ACKNOWLEDGMENTS}

The author would like to thank Mrs. Retno Damayanti and Mr. Tatang Wahyudi. Both is the researchers at the Research Development Centre for Mineral and Coal Technology - Bandung, who have provided guidance. Thanks also to the staff of Geomechanics Laboratory for their assistance in completing the physical and mechanical tests of the soil. 


\section{REFRERENCES}

Al-Khafaji, A. W. and Andersland, O. B. (1992) Geotechnical engineering and soil testing. Oxford University Press.

ASTM D2216-98 (2010) 'Test methods for laboratory determination of water (moisture) content of soil and rock by mass', in Annual Book of ASTM Standards. West Conshohocken: ASTM International

ASTM D4531 - 86(2002) (2010) 'Standard test methods for bulk density of peat and peat products', in Annual Book of ASTM Standards. West Conshohocken: ASTM International.

ASTM D698-00 (2012) 'Standard test methods for laboratory compaction characteristics of soil using standard effort (12 $400 \mathrm{ft}-\mathrm{lbf} / \mathrm{ft} 3$ $(600 \mathrm{kN}-\mathrm{m} / \mathrm{m3}))^{\prime}$, in Annual Book of ASTM Standards. ASTM International, p. 13.

ASTM D854-02 (2010) 'Standard test methods for specific gravity of soil solids by water pycnometer', in Annual Book of ASTM Standards. West Conshohocken: ASTM International.

Bowles, J. E. (1984) Physical and geotecnical properties of soil. 2nd Ed. New York: McGraw-Hill.

Bowles, J. E. (1991) Sifat-sifat fisis dan geoteknis tanah (mekanika tanah). 1st Ed. Edited by J. K. Hainim and Y. Sianipar. Jakarta: Erlangga

Das, B. M. and Sobhan, K. (2016) Principles of geotechnical engineering. 9th Ed. CENGAGE Learning Custom Publishing.

Muda, A. (2016) 'Model pendekatan alat uji kepadatan ringan untuk tanah di laboratorium', Info-Teknik, 17(1), pp. 5368.

Novalia, A. (2017) Studi eksperimen derajat kepadatan tanah standard proctor laboratorium terhadap alat tekan pemadat modifikasi menggunakan tanah timbunan pilihan. Universitas Lampung.

Pan, W., Boyles, R. P., White, J. G. and Heitman, J. L. (2012) 'Characterizing soil physical properties for soil moisture monitoring with the North Carolina environment and climate observing network', Journal of Atmospheric and Oceanic Technology, 29(7), pp. 933-943. doi: 10.1175/JTECHD-11-00104.1.

Sembiring, N., Iswan and Jafri, M. (2016) 'Studi perbandingan uji pemadatan standar dan uji pemadatan modified terhadap nilai koefisien permeabilitas tanah lempung berpasir', Journal Rekayasa Sipil dan Desain, 4(3), pp. 371-380.

Syafruddin (2007) 'Hubungan teoritis antara berat isi kering dan kadar air untuk menentukan kepadatan relatif', InfoTeknik, 8(2), pp. 142-150.

Tuheteru, E. J., Gautama, R. S. and Kusuma, G. J. (2016) 'Studi kompaksi batuan penutup untuk pencegahan terbentuknya air asam tambang pada metode enkapsulasi', Indonesian Journal of Urban and Environmental Technology, 8(2), p. 130. doi: 10.25105/urbanenvirotech.v8i2.1420.

Ulfa, S. Z. (2017) Studi konversi energi pemadatan tanah dengan modified proctor method untuk tanah pasir berlempung. Universitas Lampung.

Yamali, F. R. (2016) 'Analisa energi alat pemadat tanah lempung dilapangan', Jurnal Civronlit Unbari, 1(1), p. 33 doi: $10.33087 /$ civronlit.v1i1.10. 